\author{
Research Article
}

www.ijrap.net

\title{
A RETROSPECTIVE STUDY ON THE EFFICACY OF PANCHAKARMA CHIKITSA AND PHYSIOTHERAPY IN KATISHOOLA (LOW BACK PAIN) WITH SPECIAL REFERENCE TO THE CAUSATIVE FACTOR
}

\author{
B S Prasad ${ }^{1}$, Pradeep L Gramapurohit ${ }^{2}$, Deepti B Bagewadi ${ }^{3}$, Shilpa S Biradar ${ }^{4 *}$, \\ Pusuluri Y V S Murali Krishna ${ }^{4}$ \\ ${ }^{1}$ Principal \& HOD, Department of Kayachikitsa, KAHER's Shri B. M. Kankanawadi Ayurveda Mahavidyalaya, PG \\ Studies, KLE Ayurveda Hospital and MRC, Shahapur, Belagavi, Karnataka, India \\ ${ }^{2}$ Reader, Department of Panchakarma, KAHER's Shri B. M. Kankanawadi Ayurveda Mahavidyalaya, PG Studies, KLE \\ Ayurveda Hospital and MRC, Shahapur, Belagavi, Karnataka, India \\ ${ }^{3}$ Assistant Professor, Department of Panchakarma, KAHER's Shri B. M. Kankanawadi Ayurveda Mahavidyalaya, PG \\ Studies, KLE Ayurveda Hospital and MRC, Shahapur, Belagavi, Karnataka, India \\ ${ }^{4}$ PG Scholar, Department of Panchakarma, KAHER's Shri B. M. Kankanawadi Ayurveda Mahavidyalaya, PG Studies, \\ KLE Ayurveda Hospital and MRC, Shahapur, Belagavi, Karnataka, India
}

Received on: 12/09/17 Accepted on: 26/12/17

\author{
*Corresponding author \\ E-mail: karssb760@gmail.com
}

DOI: $10.7897 / 2277-4343.09234$

\begin{abstract}
Low back pain affects people of all ages; it is a very frequent reason for medical consultation. Pain in the lower back restricts the activity, reduces work capacity and also quality of life. The 2010 Global Burden of Disease Study estimated that low back pain is among the top 10 diseases and injuries that account for the highest number of DALYs (disability-adjusted life years) worldwide. Low back pain results due to several stressful factors seen in professional or social life and also due to incorrect postural habits. Retrospective analysis was done of 65 IPD patients for the period of 6 months in KLE Ayurveda hospital and medical research centre, Shahapur, Belagavi. The causes and the symptoms were analysed and rectified appropriately which resulted in $80 \%-90 \%$ of improvement. Bahir parimarjana chikitsa (external treatment) and antah parimarjana chikitsa (internal treatment) are beneficial when they are applied according to the need. Healthy condition of Snayu (ligaments), Kandara (tendons), Peshi (muscles) and Shleshmadhara kala is prime important which can be maintained with the help of Panchakarma and Physiotherapy.
\end{abstract}

Keywords: Katishoola, Panchakarma, Physiotherapy, Low back pain

\section{INTRODUCTION}

Kati pradesha (low back region), when afflicted with suddha vata (only vata) or sama vata (vata along ama), associated with ruja (pain) and stabdhata (stiffness), is called as Katigraha/ Katishoola (low back ache) $)^{1}$. There are also references of Kati Shoola as a symptom of some disorders such as Kati Graha, Trika Graha, Prushta Graha, Trika Shoola, Prushta Shoola, Vataja Shoola, TrikaVedana, and Grudrasi Vata ${ }^{2,3,4}$. This condition can be compared to low back pain on the basis of symptoms. Kati Shoola (low back pain) is a condition which is mainly caused by vitiation of Vata Dosha. Pain in the lower back restricts the activity, reduces work capacity and also quality of life. The 2010 Global Burden of Disease Study estimated that low back pain is among the top 10 diseases and injuries that account for the highest number of DALYs (disability-adjusted life years) worldwide ${ }^{5}$. It is seen due to several stressful factors seen in professional or social life and also due to wrong postural habits affecting both men and women alike and common in the age group of 20 to 60 years.

20-60 years of age is a wider range to reflect because it is from teen age to old age.

The external as well as the internal treatment like Panchakarma has the wide range of approach in many diseases. Basti, the rectal administration of medicines traverses all over the body and the disease is cured as the sun dries up the earth with its rays ${ }^{6}$.
Physical therapy attempts to address the illnesses, or injuries that limit a person's abilities to move and perform functional activities in their daily lives. Manual therapy, exercise therapy, electrotherapy and various physical therapies remediates impairments and promotes mobility, function, and quality of life.

Every disease may not be pathological; it may also be due to alteration in the normal physiology and anatomy of the individual. When the root cause and symptoms are clearly understood then it becomes easier for the management. Thus a retrospective study of 65 patients is being presented highlighting the cause and the management accordingly.

\section{AIM AND OBJECTIVE}

1. To identify the causative factor for the katishoola.

2. To identify the common age group and the occupation involved.

3. To identify the effect of combined treatment of Panchakarma and Physiotherapy.

\section{MATERIALS AND METHODS}

Source of Article: Retrospective analysis was done of 65 IPD patients for the period of 6 months at KLE Ayurveda hospital and medical research centre, Shahapur, Belagavi. Study was carried 
out as per International conference of Harmonization-Good Clinical Practices Guidelines (ICH-GCP)

\section{Inclusion Criteria}

- Age group of 18-75 years of either sex.

- Patients presenting the classical symptoms of Katishoola.

- Irrespective of HTN, DM history.

\section{Exclusion Criteria}

- Cases of Grudrasi (sciatica)

- Cases which did not complete the treatment.

- Unknown cause.

- History of surgery to low back.

\section{Treatment adopted}

- Bahya Snehana performed in the form of Abhyanga, Kati Basti, Kati pichu.

- Bahya Swedana in the form of Nadi Sweda, Sarvanga Bhaspa Sweda, Patra Pinda Sweda, Kati lepa.

- Basti - Niruha Basti like Erandamoola Niruha Basti, Dashamoola Niruha Basti

- Anuvasana basti was performed either alone or in combination with Niruha Basti with various vata hara Taila.

- Physiotherapy - HMP (hot moist pack), IFT (Interferential therapy) and Exercises like Isometrics were performed. All the treatments were performed for around 7- 8 days as per the need of the condition.

Table 1: Gender wise Distribution of Patients

\begin{tabular}{|c|c|c|}
\hline Total No. of Katishoola Patients & Male & Female \\
\hline 65 & $49.23 \%$ & $50 \%$ \\
\hline
\end{tabular}

Table 2: Age wise Distribution of Katishoola patients

\begin{tabular}{|c|c|}
\hline \multicolumn{2}{|c|}{ Katishoola (18-75 years) } \\
\hline $18-27$ & $10.7 \%$ \\
\hline $28-37$ & $20 \%$ \\
\hline $38-47$ & $18.46 \%$ \\
\hline $48-57$ & $16.92 \%$ \\
\hline $58-67$ & $21.53 \%$ \\
\hline $68-77$ & $12.30 \%$ \\
\hline
\end{tabular}

Table 3: Occupation wise Distribution in Katishoola

\begin{tabular}{|c|c|}
\hline Farmer & $18.46 \%$ \\
\hline Business/job/service/social worker & $20 \%$ \\
\hline Driver/mechanic & $6.15 \%$ \\
\hline Labour & $4.61 \%$ \\
\hline Housewife & $47.69 \%$ \\
\hline Student & $3 \%$ \\
\hline
\end{tabular}

Table 4: Observation on the Basis of Causative Factor/ Symptom

\begin{tabular}{|c|c|c|c|c|c|c|c|}
\hline Katishoola & No. of Patients & Age & Male & Female & Occupation & History & Improvement \\
\hline $\begin{array}{c}\text { Catching type of } \\
\text { pain/spasm }\end{array}$ & $6.15 \%$ & $42-55$ years & $3 \%$ & $3 \%$ & Housewife & Fall & $80 \%$ \\
\hline Postural & $10.7 \%$ & $20-50$ & $6 \%$ & $4.61 \%$ & $\begin{array}{c}\text { Student, busines, labour, } \\
\text { home maker }\end{array}$ & NA & $70 \%$ \\
\hline Spasm & $23 \%$ & $18-45$ & $9 \%$ & $13.8 \%$ & $\begin{array}{c}\text { Agriculture, mechanics, } \\
\text { home maker }\end{array}$ & & $80 \%$ \\
\hline Postural and spasm & $60 \%$ & $32-75$ & $29 \%$ & $\begin{array}{c}30.7 \% \text { (home } \\
\text { maker) }\end{array}$ & All types of job holders & & $90 \%$ \\
\hline
\end{tabular}

\section{RESULTS AND OBSERVATION}

Gender wise distribution: Among 65 patients, the percentage of distribution in male and female were more or less equal. It depicts that male and female are equally affected irrespective of job. In that $50 \%$ were found to be female.

Age wise distribution: Minimum age analysed was 18 and the highest being 77 years. In the range of 58-67years there were $21 \%$ patients; reason might be the chronicity of the disease and the delayed approach to the doctor for the management. 20\% of patients belonged to 28-37 years which is the peak time of hard work and the young age.

Occupation wise distribution: The data shows that Katishoola has not leftward any field of workers. On the whole, again the percentage of housewife were more in number with $47.69 \%$, because of long standing, wrong postural habits while doing works etc. Another thing to notice is $50 \%$ of the study population were females and housewives, which involves a lot of physical stress like bending forward, lifting heavy objects, prolonged standing Etc.

Observation on causative factors: The patients with history of fall complained catching pain, spasm at low back region, with no any history of surgery. When this group of patients were subjected to bahir parimarjana chikitsa (external treatment) like Sarvanga Abhyanga (body massage), Kati basti (pooling of oil on the affected site), Sthanika nadi sweda (steam bath to the affected site), Bhaspa sweda (steam bath), Patra pinda sweda, Kati pichu and Kati lepa could benefit $70-80 \%$ without the internal treatment.

Patients complaining of spasm with $\mathrm{H} / \mathrm{O}$ poor postural habits were $60 \%$ which is highest percentage to consider, in this $30.7 \%$ is contributed by housewives. Here both Bahir parimarjana 
chikitsa and antah parimarjana chikitsa like Niruha basti (enema) in various combinations along with Matra basti (oil enema) and physiotherapy was adopted leading to muscle and bone strength with relief up to $90 \%$.

$10 \%$ of patients had mild back ache only due to improper postural habits. Here the patients were treated only with physiotherapy like exercises, advice of proper posture and modalities like IFT, HMP were adopted before exercise. Only Physiotherapy was the primary management adopted. This benefitted patients up to $70 \%$.

$23 \%$ patients had the complain of spasm / stiffness leading to discomfort in walking, bending and getting up from sitting position. These patients were subjected to both Antah and Bahir parimarjana chikitsa, which benefitted up to $80 \%$.

\section{DISCUSSION}

Kati Shoola is not mentioned as a separate disease in any of the Brihatrayees directly. The quotation "Hetu Sthaana Visheshat $\mathrm{Ca}$ Bhavet Roga Vishesha Krit", treat the cause and the disease according to the site ${ }^{7}$. Sandhi is a place where two or more structures unite. Snayu (ligament), Kandara (tendons) help in proper binding of the joints resulting in proper pronation and prevents the excessive undesirable motion.

The shleshmadhara kala provides lubrication for the bony joints and enable them to move freely. It helps the joints to overcome the shock and strain of repeated movement. Functionally, this kala can be compared to the synovial membranes covering the inner surfaces of the joints. Vitiation of Vata causes pathologies of these structures leading impaired functioning. Sleshmadhara kala owns the properties of snigdha (sticky), guru (heavy), picchila (sliminess) which dries up in aggravated vata. This aggravated vata is bought to normalcy by inducing the snehana, swedana Karma. Bahya Snehana Swedana aid more in relieving muscle spasm and contribute in easing the lumbar movements. This shows that the spasm and catching type of pain is better relieved with the external therapy because in any trauma there is muscle guarding which leads to the pain and the stiffness.

In general, low back pain is more commonly seen in heavy manual workers, particularly occupations that involve heavy lifting of weight, improper postures and twisting. (Ex: construction, mining, agriculture and nursing). Improper postural habits lead to the deformity in the vertebral column and the surrounding structures. Thus, the guidance of proper posture, Physiotherapy modalities and interventional Panchakarma were helpful.

Sitting, standing and sleeping in an improper posture i.e. bad posture plays significant role in the genesis of the disease. Here bad posture increases the strain on the discs and ligaments causing faster disc degeneration. Hence bad posture is the cause of disc rupture or prolapse and it leads to pain in the low back ${ }^{8}$. Thus, the interventional Panchakarma is beneficial to decrease the fast progression of disease with the help of Basti. Because Basti has the capacity to reach the whole body.

\section{CONCLUSION}

Kati Shoola may occur independently or as a complication of any disease. So, one has to go with detail history and clinical examination to rectify cause as well as the signs. Management depends on the stage such as Svatantra or Paratantra, Naveena or Purana, Sama or Niraama. Kati Shoola can be effectively managed by judicious use of Panchakarma, Physiotherapy and ideal lifestyle.

\section{REFERENCES}

1. Bhava Mishra. BhavaPrakash with Vidyotini Hindi Commentary by Pt. Sri BrahmashankaraMishra, Varanasi, Chaukhambha Sanskrit Sansthan, Part II; p.286; $26: 53$.

2. Sharma P V, editor. Charaka Samhita, Chikitsa Sthana, Vata Vyadhi Chikithsa Adhyaya, 28/28. 2nd ed. Varanasi: Chaukhamba Sanskrit Sansthan; 1990. p. 225.

3. Murthy K R, editor. Susruta Samhita, Nidanasthana, Vata Vyadhi Nidana 1/20. Varanasi, India: Chaukhambha Orientalia; 2000. p. 102-10.

4. Murthy K R, editor. Madhava Nidana, Vata vyadhi Nidana 22/14, 57. Varanasi, India: Chaukhambha Orientalia; 1986. p. $65-90$.

5. Duthey B. Background paper 6.24 low back pain. World Health Organisation (WHO)(ed.) Priority medicines for Europe and the world 'A public health approach to innovation'. Geneva: WHO. 2013 Mar 15, p. 6.24-5 [cited 2017 Oct 21. Available from: www.who.int/medicines/areas/priority_medicines/BP6_24L BP.pdf

6. Acharya Jadavji Trikamji. Charaka Samhita, Siddhisthana, Choukambha publication 2001 Varanasi. Chapter-7, Sloke64, p. 937

7. Gupta S, Patil V, Sharma R. Diagnosis and Management of Katishoola (Low Back Pain) In Ayurveda: A Critical Review. Ayushdhara. 2017 Mar 3;3(4) p. 768.

8. David A Wong, Ensor Transfeldt. "Macnab's Backache", Lippincott Williams and Wilkins Publication.4th ed. 20

\section{Cite this article as:}

B S Prasad et al. A retrospective study on the efficacy of panchakarma chikitsa and physiotherapy in katishoola (low back pain) with special reference to the causative factor. Int. J. Res. Ayurveda Pharm. 2018;9(2):49-51 http://dx.doi.org/10.7897/ 2277-4343.09234

Disclaimer: IJRAP is solely owned by Moksha Publishing House - A non-profit publishing house, dedicated to publish quality research, while every effort has been taken to verify the accuracy of the content published in our Journal. IJRAP cannot accept any responsibility or liability for the site content and articles published. The views expressed in articles by our contributing authors are not necessarily those of IJRAP editor or editorial board members. 